\title{
REPARATIVE SUBSTITUTION AND THE 'EFFICACY OBJECTION': TOWARD A MODIFIED SATISFACTION THEORY OF ATONEMENT
}

\author{
JOSHUA R. FARRIS, S. MARK HAMILTON* \\ Houston Baptist University \& Free University of Amsterdam
}

\begin{abstract}
The doctrine of the atonement is a subject of perpetual curiosity for a number of contemporary theologians. The penal substitution theory of atonement in particular has precipitated a great deal of recent interest, being held up by many (mostly evangelical) Protestants as 'the' doctrine of atonement. In this essay, we make a defense against the objection to the Anselmian theory of atonement that is often leveled against it by exponents of the Penal Substitution theory, namely, that Christ's work does not accomplish anything for those whom it appears he undertakes his atoning work, but merely makes provision for salvation.
\end{abstract}

KEY WORDS: atonement, substitution, sufficiency-efficiency, Anselm, mechanism

\section{Introduction}

Compared one to another, some theories of the atonement simply 'do' more than others. What one thinks their theory of atonement 'does' has much to do with both the collective and individual voices of the theological tradition that inform what they believe, and these are in some sense negotiable, depending on the sort of tradition with which they ally themselves. In what follows, we take a look at an aspect of what we might think of as the logical deposit of what has become the dogmatic inheritance of the broader Reformed (i.e., Protestant), but particularly evangelical, tradition as it pertains to the (penal substitution theory of) atonement.

Generally speaking, when we talk about the atonement 'doing' this or that we are talking primarily about the interplay of two concepts: (1) the socalled mechanism of the atonement and (2) the effectual bearing that this mechanism has upon those for whom it was divinely purposed. For its supposed failure to achieve said effect, the Anselmian satisfaction theory of

* JOSHUA R. FARRIS (PhD 2015, University of Bristol) is Assistant Professor of Theology at Houston Baptist University and Visiting Fellow at Heythrop College, University of London. Email: jfarris@hbu.edu; S. MARK HAMILTON (MPhil 2013, University of Bristol) is a PhD candidate at the Free University of Amsterdam. 
atonement is often criticized, and that, by mostly penal substitution theorists. This is what we mean by the efficacy objection, namely, that the satisfaction theory simply does not do anything for humanity, but merely makes provision of the possibility of salvation. Before we describe the theories, we need to define some terms. Because we will be using several terms of art to make our case, for the sake of clarity, consider our use of following terms:

(1) 'Mechanism' describes that thing which must necessarily obtain in order for some precise act or action to obtain.

(2) 'Sufficiency' is the capacity of doing something in a right manner (e.g.: Being in possession of enough of a small-pox vaccination to administer it to an entire village).

(3) 'Efficiency' is the thing done in a right manner (e.g: Administering the smallpox vaccination to those in the village who need and want it).

(4) 'Efficacy' describes the thing done (e.g.: Those in the village to whom the small-pox vaccination was administered are insulated from the threat of contracting small-pox).

With these terms in mind, in what follows, we offer up several arguments against the efficacy objection to the satisfaction theory, arguing in favor of what we have elsewhere referred to as reparative substitution theory of atonement, which is our attempt at a sort of Protestantized version of Anselm's theory [for more on reparative substitution, see: Farris and Hamilton 2017; Hamilton 2015]. Be not mistaken though, reparative substitution is much more than that increasingly popular exercise of simply re-branding the atonement that appears so novel in contemporary constructive theology. Rather, it is more like a development of aspects of Anselm's theory that he left largely undeveloped; these developments being significant enough in our minds as constitutive of a theory separate unto itself.

To this end, this paper unfolds in two parts to a conclusion. In part one, we set up the problem by a brief discussion of the mechanism of the atonement, situating our discussion in the so-called sufficiency-efficiency debate [For more on this soteriological dictum, Satisfactio Christi sufficienter pro omnibus, sed efficaciter tatum pro electis (the atonement of Christ is sufficient for all but efficient only for the elect), and its controversial use in the Reformed theological tradition, see: Heppe 1950: 475-9 and Bavinck 2006: 455ff]. In part two, we lay out some of the contours of the penal substitution, satisfaction and finally reparative substitution theories, paying particular attention to some of those contours of the later which we take to be deliverances from the efficacy objection. By way of conclusion we offer up several reasons for thinking that, in point of fact, when compared to the reparative substitution theory, it is actually the penal substitution theory of atonement that we think has more for which to answer. 


\section{Mechanism, Sufficiency, and Efficiency}

What constitutes a legitimate theory of atonement? The answer to this is a bit tricky. For the sake of argument, a theory of atonement is legitimate according to the degree to which we can discover some mechanism that specifically describes the work that Christ accomplishes by his death. What this means, first of all, is that neither the incarnation nor the resurrection are the atonement, as some like to think (more in a moment). Following from this, it also means that there are several illegitimate theories of atonement. In this we agree with Kathryn Tanner who has recently and boldly asserted, for example, that, 'Christus Victor is not a model of atonement at all in that it fails... to address the question of the mechanism of the atonement' (Tanner 2010: 253). Is this too strong? Perhaps not. For, are not those who would resist discerning a definitive mechanism for the atonement not by consequence resistant to an intelligible explanation of the significance of the death of Christ?

Our answer to this question limits our atonement options, to be sure. For not only is Aulen's Christus Victor thus undermined on this way of thinking, but so also is Abelard's Moral Exemplar theory and perhaps even (ironically) Tanner's Incarnation as Atonement theory. This is because these theories, save for some theologically constructive refashioning-something to which we are not at all opposed-are not really 'doing' anything, that is, doing anything as it pertains to the death of Christ that is efficient for humanity (see, e.g.: Myers 2015: 71-88). Tanner endorses an incarnation theory of atonement that supposedly undoes any talk of legality where God is somehow bound to the law he has set in motion from the beginning of creation. What she highlights are the benefits humans receive from the incarnation. All that is required on her theory appears to be that God desires to be in union with humanity and God making his life available to humans exemplified to the greatest degree in the incarnation. The problem with this theory is that it does not sufficiently account for the Fall as an objective break between the divine and human relationship. We are not convinced that Scripture nor logic gives us reason to think that the incarnation itself accomplishes something like justification (i.e., making us right with God and / or his moral law). In fact, neither is this theory necessarily performing a work-again, as it pertains to the death of Christ-that ought to be regarded as sufficient for humanity. Such theories seem intent on leveraging a perceived measure of explanatory power afforded by other doctrines in order to interpret the value of Christ's death.

Now, we will be the first to admit that such theological moves are not

entirely out of order. The problem is when such moves are over-leveraged to such a degree that Christ's death is not able to be explained without 
them. Of course, Christ could not die were he not incarnate. But the incarnation is not the atonement, no more than, say, creation is providence. Certainly, they bear a close conceptual relationship. But they are not numerically the same. For a theory to be considered a theory unto itself, the act of Christ's death must itself accomplish something. It must, that is, have some singular and definable efficacy.

For legitimate theories of atonement, particularly those that fall under the category of a restitution model, which is our interest here, the death of Christ has been traditionally regarded-at least since Lombard's proposal of the sufficiency-efficiency distinction-as accomplishing one of the following three redemptive goals:

A. Either the the death of Christ is a work that makes atonement that is sufficient for all humanity but efficient for none (e.g. the satisfaction theory) or

B. is sufficient for all humanity and efficient for some (e.g. the penal substitution theory) or

C. is sufficient and efficient for all, e.g. the universalist, salmurian, and reparative substitution theories of atonement (Franks 2001: 358). Interestingly, Franks describes the salmurian theory as both sufficient and efficient for all, 'on the condition of faith' (p. 358). This result is somewhat oddly similar to the satisfaction theory, faith being an integral part, though perhaps not the whole, of those conditions for salvation that Anselm had in mind.

It is within the constraints of this still important theological distinction, where the question of most interest to us surfaces, namely, 'What does a given theory actually accomplish', if anything, or more precisely, 'What does it accomplish for humanity' (if anything)? To answer this question, let us briefly take a closer look at the mechanism of atonement, first on penal substitution theory and then on the satisfaction theory, after which we will look more closely at the reparative substitution theory, which to our minds offers the most promise of doing something for humanity, and what is more, for God himself.

\section{Mechanism, Efficacy, and Penal Substitution}

Penal Substitution is (roughly) the theory according to which Christ assumes the legal responsibility for the $\sin (\mathrm{s})$ of human beings and by his substitutionary death pays their debt of punishment in order to satisfy God's retributive justice. A development of the Protestant Reformation (Shedd 2003: 451-55), penal substitution has since become the majority soteriological report amongst many contemporary Protestant evangelicals. Unfortunately, this majority also thinks by-and-large that the doctrine of penal substitution has been genetic and therefore dogmatic fixture of the church going back as far as Irenaeus and Athanasius (Jeffery 2007). Such '[gross 
distortions]' have of course been challenged (Vidu 2014: 1). According to Adonis Vidu's recent and thoroughgoing treatment of the historical development of the doctrine of the atonement, penal substitution makes its first full appearance with Calvin. Then, Vidu carefully and helpfully exposits Berkhof's four points of departure from the Anslemian tradition that appear with Calvin, and here we quote him at length,

First, the satisfaction theory focuses on the honor and dignity of God rather than his justice. The context is that of private rather than public law. Second, there is no place in Anselm's thought for the biblical idea of Christ's bearing of our punishment on our behalf. Rather, Christ offers himself as a sacrifice acceptable in lieu of our being punished (Isaiah 53:10). Third, Berkhof argues that there is no place for the active obedience of Christ. This might seem puzzling, yet it is not the death that effectively procures atonement for Anselm, but the infinitely valuable offer of Christ's life. Finally, the fourth weakness sensed by the Reformers is that the Latin satisfaction model turns on a purely external transfer of merits. The believer is left to his or her own devices to continue to earn the surplus merit of Christ. While, as we shall see, an economy of exchange will continue to characterize the Reformed understanding of the atonement, the satisfaction of God is construed in such a way that it can only be accomplished by the redeemer, and cannot be replicated by believers seeking to earn salvation. Christ's work is final (Hebrews 7:27; 9:28; 1 Peter 3:18) and unrepeatable (Vidu 2014: 118-9).

Vidu then launches into a more elaborated treatment of the particulars of Calvin's thought, paying particular attention to his account of divine love, law, and wrath as they relate to the atonement, from which we are able to discern no less than five distinctive component parts of the penal substitution theory; components which appear common to its various expressions in the literature since. These include:

(1) Christ's atonement is necessary to his redemptive work.

(2) Christ's death is sufficient to assuage divine wrath for all humanity.

(3) Christ dies as a penal substitute for individual persons.

(4) Christ dies in order to absorb the retributive (penal) consequences of divine justice and wrath precipitated by human sin, being treated by God as if he were those individuals to whom the punishment were due (i.e. the mechanism).

(5) Christ's death pays a debt of punishment.

(6) Christ's death is a vicarious sacrifice.

Now, the mechanism of the penal substitution theory is bound up in the act of Christ's death absorbing the cumulative force of divine retributive justice (i.e. wrath) against sins of particular human persons (some number of human persons less than the total number) whom Christ is said to represent. [It is worth some additional clarification at this point, that by absorbing wrath, Christ is not hated by God, as some have recently and foolishly sug- 
gested. It appears that is no longer enough to simply believe that Christ died as a penal substitute. In some evangelical quarters, it now seems necessary to believe that as a penal substitute, Christ's endurance of the wrath of his Father's justice makes him the object of God's hatred, albeit temporarily. Such thinking, when worked out with greater logical precision and rigor seems to fall under the category of 'broken-Trinity theology', recently discussed in Thomas McCall (2012). In this act, Christ's death pays the debt of punishment owed by those over whom he is a so-called federal head. Paying the debt of punishment is what this theory does and absorbing this penalty for those whom he represents is what this theory does for humanity.

The 'sufficiency-efficiency' distinction is often deployed by exponents of penal substitution to defend this mechanism. Generally, they seem to think that Christ's death is sufficient to absorb the wrath of God for all but is effectually restricted in application to only certain individuals, and that by divine decree. Interestingly, this is not the only way exponents of penal substitution defend this mechanism. Some argue for a definite atonement and think that God decrees that Christ die as the legal representative (i.e. penal substitute) for particular individuals. This is quite different for those who believe in a limited atonement and think that God decrees that the benefits accruing from Christ's representative work be conferred only upon those whom he chooses. More interesting still is the fact that some penal substitution theorists have argued that Christ's work is both sufficient for all and efficient for all (e.g. Universalism or Salmurianism). [It is of additional and interesting note, at this point, that the atonement theories proposed by those associated with the minority report within the Reformed traditionhypothetical universalism-their own subtle differences notwithstanding, are likewise committed to this same mechanism, which ironically leads to what is often called the 'double payment objection'. This is not a little problem for which penal substitution theorists have yet to offer a strong rebuttal (Crisp 2014: chapter 7).] However, this distinction is construed, the central question is still one of mechanism: did Christ's death pay a debt of punishment and did he do so (definitively) for particular individuals? Not according to Anselm.

\section{Mechanism, Efficacy, and Satisfaction}

According to what we might think of as a classical Anselmian Satisfaction theory, Christ gives up his life in order to restore honor to God by paying a debt, one that satisfies the creditor; not a debt of punishment (as in the case of penal substitution), but a debt of honor. This again, is something that Vidu carefully treats at length, and in concert with the broader articulation and later development of the satisfaction theory amongst Abelard, Aquinas, and Duns Scotus (Vidu 2014: 45-88). Hitting on the major themes related 
to Anselm's satisfaction theory-his Platonic and realist philosophical assumptions, his theological approach to law, his emphasis on the private (rather than the public) offense of sin, his contrast of punishment versus satisfaction, the necessity of the incarnation, the sufficiency of Christ's meritorious work to pay humanities debt to God-Vidu shows with great precision and clarity why Anslem's theory became epoch-making for later medievals. We see the trace elements of Vidu's treatment of Anselm in such statements as those from Cur Deus Homo:

[S]in is nothing other than not to give God what is owed him. Therefore, everyone who sins is under obligation to repay to God the honour which he has violently taken from him, and this is the satisfaction which every sinner is obliged to give to God (1.11). [I]f there is nothing greater and nothing better than God, then there is nothing, in the government of the universe, which the supreme justice, which is none other than God himself, preserves more justly than God's honour (1.13). To forgive sin in this way [that is, by mercy alone, without reparation] is nothing other than to refrain from inflicting punishment. And if no satisfaction is given, the way to regulate sin correctly is none other than to punish it (1.12). It is a necessary consequence, therefore, that either the honour which has been taken away should be repaid, or punishment should follow' (Anselm 1998, $283,286,288,349)$.

Summarily speaking, Anselm's theory can be expressed (roughly) in the following set of numbered theses:

(1) Christ's atonement (or a suitable equivalent) is necessary to his larger redemptive work.

(2) Christ's death procures an infinite merit (i.e. the mechanism); The infinite merit of Christ's death pays a debt of honor to God.

(3) Christ's death is a work of supererogation and therefore sufficient for all humanity.

(4) Christ's death is efficient for those who by faith are united to Christ.

It should be clear from this that the mechanism of atonement on Anselm's theory is built around the idea that Christ's death somehow restores honor to the Father, namely, by virtue of the infinite merit of the sacrifice of his infinite self, thereby offsetting the infinite demerit of human sin. In this, Christ's act is one of equity to a debt; again, not a debt of punishment but a debt of honor.

It should also be clear that on Anselm's account of Christ's atoning work, his death is sufficient for all humanity but, interestingly, not efficient in the sense that some redemptive effect immediately obtains for humanity (or some part of humanity), as in the case of the penal substitution theory. Anselm's theory makes several other necessary conditions for salvation. In oth- 
er words, Christ's atonement, according to Anselm, is not efficacious for humanity. For it to be so, there are conditions beyond those of the work that Christ's death achieves that must be met. This, we recall, is in contrast to the penal substitution theory, exponents of which often celebrate the positive benefits that belong to the elect (i.e. propitiation, expiation, justification, and imputation) as an immediate result of Christ's death on their behalf. It is important to note that the doctrine of penal substitution is the means of making one 'right' with God. In other words, the mechanism is that of Christ bearing penalty for sins against God. Normally the nature of Christ's justifying act in the atonement is cashed out in terms of imputation, rather than as a version of realism or impartation. The doctrine of imputation is the view that God views us as if we were right or just, according to his moral law, because of Christ. However, Christ has not actually made us righteous nor has he imparted or infused righteousness into us. The problem with the doctrine of imputation is quite clear in much of the literature. Christ, as a result of assuming a debt (of punishment) he could not literally assume, he becomes a fictional representative for us whom God accepts as a legally admissible stand in, so to speak. This is what many have called the 'legal fiction' objection. Interestingly, it is the failure to claim these and other soteriological benefits as accomplished and therefore secured by Anselm's theory that are often promoted by penal substitution theorists as among the reasons to reject a straightforward satisfaction theory. In other words, for penal substitution theorists, Anselm did not go far enough (Philipps 2010: 23-5).

However, it is important to take note of the fact that not all penal substitution theorist work out the efficiency / efficacy of Christ's death for the elect in the same way. In fact, there are several ways to work out the penal substitution theory. For example, the Holy Spirit seems to have some important role in effecting the results of the atonement. So, it is not, as if, the atonement does all of the work or transmits all the soteriological benefits of Christ's work to the elect in its own right. While many contemporary Reformed theologians suggest that there is one way of working out the penal substitution theory, this is simply not the case as reflected in the Reformed tradition. [For one popular and respected Reformed theologian who endorses penal substitution and the logical necessity of the efficacy of Christ's atoning work for the elect (as understood in what is oft called limited atonement) as the theory of atonement, see, for example, R. C. Sproul in http://calvinandcalvinism.com/?p=13943 (cited on May 16, 2017). See also: R. C. Sproul in http://www.ligonier.org/learn/articles/biblical-scholasticism/ (cited on May 16, 2017).]

This is a fairly common and singular way of understanding penal substitution theory. This is, also, often used as the ground for rejecting all other atonement theories or constructions of the penal substitution theory. But as 
we will see, the discussion is quite a bit more complicated. There are several ways to work out the theory that takes into account other doctrinal loci of making sense of how it is that the benefits are transferred from Christ to the elect. For one example, we could look to William Shedd, who works out the meting out of the atonement benefits via the work of the Holy Spirit in the life of the elect. In other words, as Shedd understands the efficacy of Christ's atonement, it is the Holy Spirit the extends / applies it to the elect (Shedd 2003, 464). Alexander Hodge articulates the penal substitution of Christ to actually remove the legal demands on all people, which as we will see below, is similar to how we understand and develop Anselm's theory (Hodge 1972, see ch. 25.9, 25.10, 25.17). With these various understandings of soteriological benefits within the Reformed tradition clearly secured, we can begin to see the implausibility of linking the necessity of the penal substitution theory as the theory of atonement that offers us the only, or even necessarily, the best way to articulate efficacy. If we are honest, the efficiency / sufficiency distinction, so often employed throughout Reformation history, is quite a bit more complicated that contemporary theologians let on, even when we consider the largely celebrated penal substitution theory.

Like the penal substitution theory, it seems charitable to take each theory on its own terms and to see how the theologian works out the logic of how it is that all the soteriological benefits are appropriated in the life of the believers. It seems overly simplistic to say that the atonement does all the work of salvation when we have so many other soteriological categories in Scripture. With respect to other theories, including Anselm's theory, it is perhaps not enough to say that Anselm's theory is less than fully systematized. And it is at this particular point where we offer some additional theologically constructive specificity in the form of a new theory of atonement that we call reparative substitution.

\section{Mechanism, Efficacy, and Reparative Substitution}

Summarily speaking, according to the reparative substitution theory, Christ dies in an act of divine love to pay a debt of divine honor owed by humanity to God by offering himself up in act of supererogation that procures an infinite merit (of honor), offsetting the infinite demerit of human sin in order to satisfy the rectoral demands of divine justice, thereby restoring honor to God (and by consequence, his moral law). Consider the following nine constituent parts of reparative substitution:

(1) Christ's atonement is necessary to his work.

(2) Christ's death is an act of divine love.

(3) Christ's death procures an infinite merit (i.e. the mechanism).

(3a) The infinite merit of Christ's death pay the full sum of humanities debt of honor to God (Christ does this qua his divine nature). 
(3b) The infinite merit of Christ's death pays the full sum of humanities debt of honor [not a debt of punishment] to God's moral law (Christ does this qua his human nature).

(4) Christ's death is sufficient for all humanity (what we might call a global substitute).

(5) Christ's death efficiently defers divine wrath for all humanity until the consummation / Judgment. [Franks offers the following helpful and discriminating note, saying, 'The Remonstrants also all but abolish the satisfaction and merit of Christ, asserting that Christ died, in order that God the Father might have the right to contract with us anew, on what terms he pleased, concerning forgiveness and justification. But while Christ's obedience and death stand, there can be no other way of obtaining justification; and those, who are justified thereby, are not justified by any legal contract, but purely by grace; and being united to Christ by faith, are regenerated and purified in heart'; (Franks 2001: 440.6).]

(6) The incarnation establishes both a 'vital union' and 'legal union' between Christ and all humanity, without which Christ's work would not obtain for all humanity.

(7) The resurrection generates a newly constituted humanity, whose 'members' include those who by faith (as the 'relative' union), at the Judgment will receive their remunerative benefit.

(8) Christ's work is efficient for the 'elect' by settling all debts and eliminating eternal death.

Right away, the similarities with Anselm's satisfaction theory should be apparent, particularly those regarding Christ's payment of a debt of honor. It should also be readily apparent that unlike penal substitution, Christ bears or absorbs no penalty (perhaps not even the one demanded by the moral law, that is, unless he pays the penalty of death that the moral law demands for all humanity) on the reparative substitution theory. He remains a substitute, just not a penal one. This is because the intended mechanism of atonement is the restoration of divine honor, not the provision of opportunity for God to expend his wrath on Christ for sin.

With reparative substitution, we are asserting that the love of Christ for his Father is the primary motive in his making atonement. Christ came to restore divine honor and he cannot do it only in part. By his death, the honor of God's name-the thing for which he cares most-is publicly restored to him and not only that, but the honor of his irreproachable law is also restored (again, Christ is not penalized by the law, he is honoring the law with his active obedience; the active and passive obedience distinction is something we are in the process of developing). The demands of divine justice are universally met, and that, for all humanity. This follows from the incarnation but is achieved by Christ's making reparations by his death.

By the Son assuming human nature, as our covenantal representative, Christ enacts a new union with humanity. A union similar to the union 
found with Adam in the Creational covenant. In the new Creational covenant, Christ unites to our humanity. Christ enacts a vital and judicial union with humanity according to the moral law established by God for humanity. This new union establishes the ground for Christ paying our debt of honor to God and opens the door for newly transformed humanity at the resurrection.

What then of God's retributive justice? And what of those who ultimately reject God?-you might ask. In short, Christ's death defers the exercise of retributive justice until the consummation of all things, where both and the retributive and remunerative aspects of rectoral justice will be meted out. This is not only where Christ's atoning worth is sufficient for atonement in that his merit is available to all, but that it is efficient in staving off divine wrath for all, again, until the consummation. God's honor is literally restored by Christ's act of giving himself up as a morally perfect sacrifice to the Father.

In so doing we are proposing both a soteriological and judicial shift in our understanding of the divine economy. Retribution is not exacted from the Son, but from those who in the end reject him. Christ is therefore not punished, for he is a morally perfect human (hence, a morally perfect sacrifice to God). The efficacy is found in Christ's setting aright the moral demands of divine justice. Christ pays off our debt to God. Christ effectively pays our debt of honor to God. God is thus honored, and the moral law is satisfied in the death of Christ not by the absorption of a debt that no human can sufficiently satisfy, but by offering up a gift of honor of such a worth as to settle the due demands of the moral law.

By this, saints are truly pardoned. And with this we are in effect elevating the significance of faith-a move of which Anselm would likely approve-as well as faith's relationship to the nature of union with Christ. The result of all this, ironically, is the wholesale elimination of the need to even make the sufficiency-efficiency distinction or, at a minimum, a complex reworking of it. As we have seen, though, the distinction is not all that simple and has been worked out in numerous, albeit, arguably, consistent, ways. Christ's work, on reparative substitution, is sufficient and efficient for all. It appears that it is sufficient in that the work of Christ is of such a value that it can ultimately atone for demands of honor to God eternally. It is efficient, arguably, in the two senses listed above. It is efficient to settle the demands of the moral law and it is efficient for the elect who receive the full remunerative benefits by faith.

Two questions must be answered in the end. First, what does reparative substitution do? It restores to God the glory that was violently taken from him, who, as the apostle says, graciously 'passed over former sins', the result of which was his willingness to be dishonored for a time. Second, what does 
reparative substitution do for humanity? It defers divine retribution until all moral accounts will be settled. It fixes both the private and public problems that humanity faces for having transgressed God's rectoral justice. In this way, the reparative substitution theory is radically theo-centric, an idea we suppose few would want to publicly resist and which is the principal reason for God's patient endurance of the reproach of sinners.

\section{Conclusion}

To this point we have tried to show that a developed version of Anselmian satisfaction-what we call, reparative substitution-in no way succumbs to the penal substitution theorist's efficacy objection. Far from it, reparative substitution actually does more, so we think, than penal substitution theorist's think their theory does. For example, in what way does the penal substitution theory do anything positive or efficacious for God (pause) that is also efficacious for all humanity? Simply put, we do not think it does. To put it rather bluntly, nothing is restored to God on the penal substitution theory. Neither are the benefits that follow from Christ's work beneficial for all humanity. Instead, and quite to the contrary of the apparent demands of God's retributive justice, penal substitution seems only to make provision for God to restore righteousness to some part of humanity, leaving God dishonored and his Son, crushed (as the prophet says) for this dishonor, and what is more, all of this being of no apparent benefit to himself, save perhaps for the opportunity to vent his just wrath. In other words, upon closer examination and a comparison of mechanism and efficacy with other theories of atonement, penal substitution seems rather anthropocentric. Not so for the reparative substitution theory, according to which Christ's sacrificial act actually achieves something for all humanity and for God, namely, the restoration of divine honor.

With all that has been said, we realize that even the suggestion that a theory of atonement other than penal substitution is nothing short of anathema in some circles. Particularly, we have had in mind the evangelical community. We too identify with this community. Having been raised and nurtured in this environment, we are committed not only to the Protestant tradition with the Solas, but, more specifically, to the evangelical emphasis on the authority of Scripture, evangelism as the means for calling debtors to account, and the centrality of Christ's work as the sole means of salvation, amongst other commitments. What we have argued here and elsewhere seems to coherently and intimately grow out of these Protestant evangelical convictions. For this reason, it seems that evangelicals ought to reconsider the standard penal substitution theory of atonement and whether it can be justly regarded as the theory of atonement. Following from this, it seems that evangelicals ought to reconsider a more robust and systematized An- 
selmian theory of atonement, one that makes sense of the whole of divine justice and not just one part. The coherence of reparative substitution warrants such reconsideration.

In fact, this version of Anselm's atonement theory fares even better in terms of explanatory power (e.g., efficiency / efficacy), coherence (at least as it is compared to the standard / popular penal substitution theory), and appeal. While there is a need to develop the theory and its implications in other biblical and theological contexts, this should not detract from the merits the theory has in terms of efficiency and efficacy, as we have explained here. No doubt, advancing a theory of atonement requires additional reflection and application. Particularly, the theory deserves some reflection in the context of Christ's mission (e.g., missional theology), a common area of reflection in contemporary theology. The theory also deserves some more explicit grounding in the exposition and theological readings of various passages of Scripture, as is appropriate for any evangelical theory of atonement. Furthermore, there are several challenging (not impossible) texts that need to be reconciled and integrated with such a theory (e.g., Isaiah's suffering servant)

Again, it is worth noting that not all passages of Scripture nor all theological issues can be addressed in one article, let alone one book. What we have done here simply motivates the consideration of one novel theory in the Anselmian tradition taken in a Reformed / Protestant direction. By taking one of the most common theological objections to the Anselmian theory (as well as every theory of atonement other than penal substitution), we hope this, at a minimum, will gain a hearing from the evangelical community.

\section{Bibliography}

Anselm (1998) Why God became Man. In Davies B, Evans GR (eds) The Major Works. Oxford: Oxford University Press.

Bavinck H (2006) Sin and Salvation in Christ, volume 3. In Bolt J (ed), Vriend J (trans) Reformed Dogmatics. Grand Rapids, MI: Baker.

Crisp OD (2014) Deviant Calvinism. Broadening the Reformed Tradition. Minneapolis, MN: Fortress Press.

Franks RS (2001) A History of the Doctrine of the Work of Christ. Eugene, OR: Wipf \& Stock.

Farris JR, Hamilton SM (2017) Contemporary Restitution Models of Atonement, Divine Justice, and Somatic Death. Irish Theological Quarterly (forthcoming).

Hamilton SM (2015) Jonathan Edwards, Anselmic Satisfaction, and God's Moral Government. International Journal of Systematic Theology 17(1): 1-22. 
Hodge AA (1972) Outlines of Theology. Carlisle: Banner of Truth.

Heppe H (1950) Reformed Dogmatics. Trans. Thomson GT. London: Collins.

Jeffery S, Ovey M, Sach A (2007) Pierced for Our Transgressions: Rediscovering the Glory of Penal Substitution. Wheaton, IL: Crossway.

McCall TH (2012) Forsaken: The Trinity and the Cross, and Why It Matters. Downers Grove, IL: InterVarsity.

Myers B (2015) The Patristic Atonement Model. In Crisp OD and Sanders F (eds). Locating Atonement: Explorations in Constructive Dogmatics. Grand Rapids, MI: Zondervan.

Philipps RD (2010) What is the Atonement? Phillipsburg, NJ: P\&R Publishing. Shedd WGT (2003) Dogmatic Theology. Phillipsburg, NJ: Presbyterian and Reformed.

Tanner K (2010) Christ the Key. Cambridge: Cambridge University Press.

Vidu A (2014) Atonement, Law, and Justice. The Cross in Historical and Cultural Contexts. Grand Rapids: Baker Academic. 